\title{
Implementation of Sustainability Standard into Commodity Supply Chain Networks: A Processual Case Approach
}

\author{
Sidikat Shituํㅛ \&ohaya Mohd-Nor ${ }^{2}$ \\ ${ }^{1} \mathrm{PhD}$ Candidate, Faculty of Economics and Business, Universiti Malaysia Sarawak \\ Email: siddyshitu@yahoo.com \\ ${ }^{2}$ Associate Professor, Faculty of Economics and Business, Universiti Malaysia Sarawak \\ Email:mnrohaya@feb.unimas.my
}

DOI: 10.6007/IJARBSS/v7-i6/2941 URL: http://dx.doi.org/10.6007/IJARBSS/v7-i6/2941

\begin{abstract}
This paper investigates the process of implementing sustainability standard into shea butter supply chain networks. Using an exploratory processual case study methodology informed by Pettigrew Contextual Approach. In this paper a conceptual model was developed using the relationship among the external actors to investigate the contextual factors that support or obstruct the implementation process over a period of time. The findings suggest that the standard setting organizations are the pace-setters for the other external actors in the implementation process, while contextual factors related to socio-cultural context, historical context and political context are responsible for the slow implementation process in the supply chain networks. Research implication for the study was presented together with contributions and conclusion.
\end{abstract}

Keywords: External actors, supply chain, sustainability standards, contextual factors, shea butter industry, Nigeria.

\subsection{Introduction}

Sustainable supply chain management has become a global issue, in which academic researchers, private businesses and policy makers have developed interest in finding out why sustainability issues in supply chain continues to persists (Revilla \& Saenz, 2014, Brindley \& Oxborrow, 2014). According to the United Nation Global Compact (2010) sustainable supply chain is described as the "management of environmental, social and economic impacts and the encouragement of good governance throughout the life cycles of goods and services". As they suggest that the objective of supply chain sustainability is to create, protect and grow long-term environmental, social and economic value for all actors involved while bringing products and services to the market. Nevertheless, the implementation of sustainable supply chain standards has been extremely problematic in commodity supply chains, this may be as a result of the poor understanding of stakeholder's relationships in supply chain network and the startegies applied in the process of implementing sustainable supply chain standards. (Hamprecht 2005; Bitzer et 